Majalah Ilmiah Gema Maritim, e-issn: 2656-629x,

Vol. 23, No. 1, Maret 2021, pp. 55-62

\title{
TATANAN KEHIDUPAN BARU PADA LAYANAN PENUMPANG DI KM. MUTIARA FERINDO VII OLEH PT. ATOSIM LAMPUNG PELAYARAN CABANG SEMARANG
}

\author{
Aan Rubiyanto ${ }^{\mathbf{1}}$, Hadid Widi $\mathbf{A}^{\mathbf{1}}$, \\ ${ }^{1}$ Program Studi Nautika, Politeknik Bumi Akpelni \\ Jl. Pawiyatan Luhur II/17, Bendan Dhuwur, Semarang. \\ Email : aan@akpelni.ac.id
}

\begin{abstract}
Abstrak
Di tahun 2020 ini, dunia dilanda sebuah pandemi yang tidak pernah terduga sebelumnya. Corona Virus Disease-2019 (Covid-19) merupakan virus yang menyebabkan infeksi saluran pernafasan manusia dan berakhir kematian. Penyakit ini dengan cepat menyebar keseluruh dunia dan mengakibatkan banyak negara melakukan karantina. Waktu terus berlanjut, hingga dibutuhkan sebuah tatanan kehidupan baru bagi masyarakat agar bisa melakukan aktifitas seperti biasa. Dunia pelayaran, khususnya angkutan penumpang laut pada PT. Atosim Lampung Pelayaran juga tidak luput dari adanya perubahan sesuai aturan tatanan kehidupan baru. Penulisan ini bertujuan untuk mengetahui dan memahami tentang tatanan kehidupan baru pada masa pandemi civid-19, khususnya layanan penumpang pada pada transportasi laut di KM. Mutiara Ferindo VII, masih minimnya pemahaman penumpang dengan peraturan tatanan kehidupan baru di angkutan laut, kurang pahamnya penggunaan $e-H A C$, dan masih rendahnya rasa disiplin penumpang dalam melaksanakan tatanan kehidupan baru. Metode pengumpulan data dalam penulisan ini adalah dengan studi kasus pada PT. Atosim Lampung Pelayaran cabang Semarang secara langsung di lapangan, metode interview kepada pihak yang bersangkutan secara langsung, dan metode pustaka yaitu dengan mencari sumber bahan pustaka yang relevan. Berdasarkan pembahasan dapat disimpulkan bahwa diperlukan sinergitas dari berbagai pihak untuk bisa menjalankan protokol kesehatan, sosialisasi peraturan tatanan kehidupan baru kepada penumpang, mengalihkan HAC manual ke $e-H A C$, dan peningkatan kedisiplinan dan fasilitas kesehatan untuk menurunkan menyebaran virus Covid-19 di Indonesia.
\end{abstract}

Kata Kunci: Tatanan Kehidupan Baru, Covid-19, Protokol Kesehatan

\section{PENDAHULUAN}

Dunia saat ini sedang digemparkan dengan merebaknya virus corona yang telah menjadi pandemi global. Berawal dari kota Wuhan, Tiongkok, virus yang kemudian dikenal dengan nama Covid-19 ini menyebar tidak hanya ke antero Tiongkok, tetapi seluruh penjuru dunia. Tidak ada satu pun negara yang terbebas dari sebaran virus ini. Satu per satu korban meninggal akibat erinfeksi virus ini. Tak hanya puluhan, tetapi ratusan ribu korban jiwa di seluruh negara.

Banyaknya korban jiwa akibat virus Covid-19 ini disinyalir karena setiap negara tidak siap menghadapinya. Tidak bisa dipungkiri banyak pemerintah di berbagai negara seolah kewalahan saat "berperang" melawan virus ini. Keterbatasan jumlah tenaga kesehatan dan minimnya alat pelindung diri mengakibatkan layanan kesehatan tidak maksimal. Setiap negara melalui otoritasnya meminta masyarakat untuk tetap di rumah, menjaga jarak, bahkan karantina wilayah. Semua dilakukan semata-mata untuk menghambat penyebaran virus tersebut.

Pemberlakuan pembatasan sosial dan fisik tentu membatasi ruang gerak dan mobilitas masyarakat. Bahkan karantina wilayah mengakibatkan masyarakat tidak dapat beraktifitas di luar rumah. Banyak arus logistik harus terhenti karena terjadi banyak karantina wilayah. Industi pelayaran pun terdampak, salah satunya PT. Atosim Lampung Pelayaran. Sebagai perusahaan pelayaran nasional swasta yang melayani penyeberangan antar pulau-pulau di Indonesia juga mengalami keterbatasan 
dalam operasional kapalnya. Lambat laun pemerintah mulai membuka kembali layanan dan mengijinkan kembali aktifitas masyarakat. Dengan menerapkan protokol kesehatan yang ketat, kegiatan masyarakat mulai kembali seperti sedia kala. Tentu dengan dikeluarkannya aturan untuk mematuhi protokol kesehatan ini, tentu banyak fasilitas layanan publik mengalami perubahan. PT. Atosim Lampung Pelayaran melalui KM. Mutiara Ferindo VII juga harus mematuhi protokol kesehatan untuk tetap bisa beroperasi, khususnya pada pelayanan penumpang.

\section{LANDASAN TEORI}

\section{Pengertian Corona Virus Disease-2019}

Menurut Syafrida (2020), Corona Virus Disease-2019 merupakan penyakit infeksi saluran pernapasan yang disebabkan oleh Severe Acute Respiratory Syndrome Corona Virus 2 (SARS-CoV-2). Penyakit ini memiliki gejala yang berbeda-beda bagi para penderitanya, ada yang tanpa gejala, gejala ringan, hingga gejala berat. Gejala ringan antara lain adalah batuk, demam $>37^{\circ} \mathrm{C}$, nyeri, sakit kepala. Sedangkan untuk gejala berat antara lain sesak nafas, nyeri hebat, dan kelelahan. Penyakit ini tidak bisa dianggap mudah karena memang bisa memicu kematian. Virus ini menyebar melalui interaksi langsung dari manusia ke manusia melalui doplet saat kita berbicara, batuk, dan bersin.

Menurut Fathiyah (2020), Virus Corona merupakan keluarga Coronaviridae, yang bergenera Betacoronavirus yang hampir sama dengan virus penyebab SARS. Virus Covid-19 ini belum diketahui patogenesis infeksinya. Dapat menular dari orang ke orang melalui percikan air liur. Memiliki masa inkubasi 2-14 hari dalam tubuh manusia. Menurut Ali Chamdilah dalam Cahya Fajar (2020;162), Covid-19 adalah suatu kelompok virus yang menyebabkan penyakit pada hewan atau manusia. Beberapa jenis coronavirus diketahui menyebabkan infeksi saluran pernapasan pada manusia mulai dari batuk pilek hingga yang lebih serius seperti Midle East Respiratory Syndrome (MERS) dan Severe Acute Respiratory Synderom (SARS). Coronavireus jenis baru yang ditemukan memyebabkan penyakit CoVid-19. Dengan kata lain, CoVid-19 adalah penyakit menular yang disebabkan oleh jenis coronavirus yang beru ditemukan. Ini merupakan virus baru dan penyakit yang sebelumnya tidak dikenal sebelum terjadi wabah di Wuhan.

\section{Pengertian Tatanan Kehidupan Baru}

Dalam beberapa waktu terakhir, muncul istilah baru, yaitu "tatanan kehidupan baru" atau bisa disebut "normal baru". Tatanan kehidupan baru atau normal baru adalah suatu cara hidup baru atau cara baru dalam menjalankan aktivitas hidup ditengah pandemi Covid-19 yang belum selesai. Sigit menerangkan, normal baru dibutuhkan untuk menyelesaikan masalah kehidupan selama pandemi Covid-19. Sigit mencontohkan, normal baru ini sebagai alternatif sebagai dasar kebijakan nasional untuk memenuhi kebutuhan konsumsi. Karena, konsumsi masyarakat berhubungan dan kegiatan produksi dan distribusi. Selain itu, dia menjelaskan, kondisi sosial juga membutuhkan interaksi. Juga, kegiatan keagamaan yang tidak mungkin terus-menerus mengurung penganutnya dalam ruang daring.

Menurut Viryan dalam Charles Robert Darwin (2020), melalui bukunya The Origin of Species, memperkenalkan teori ilmiah tentang populasi yang berevolusi dari generasi ke generasi melalui seleksi alam.

Munculnya kebiasaan baru dalam pandemi ini yang menggunakan siku sebagai pengganti telapak tangan. Begitu juga kebiasaan mencuci tangan dan saling menjaga jarak fisik.

Jadi tatanan kehidupan baru atau normal baru dapat diartikan suatu kondisi dan atau kebiasaan sosial masyarakat atau perilaku individu yang muncul setelah pandemi ini selesai. 


\section{Pengertian Pelayanan}

Menurut Moenir (2010), pelayanan adalah proses pemenuhan kebutuhan melalui aktivitas orang lain secara langsung. Standar dalam pelayanan adalah ukuran yang telah ditentukan sebagai suatu pembakuan pelayanan yang baik. Dalam standar pelayanan ini juga terdapat baku mutu pelayanan. Adapun mutu merupakan kondisi dinamis yang berhubungan dengan produk, jasa, manusia, proses dan lingkugan yang memenuhi atau melebihi harapan pihak yang menginginkan.

Menurut Sampara Lukman yang dikutip oleh Sinambela (2014), pelayanan adalah suatu kegiatan atau urutan kegiatan yang terjadi dalam interaksi langsung antar seseorang dengan orang lain atau mesin secara fisik, dan menyediakan kepuasaan pelanggan.

\section{Pengertian Penumpang}

Menurut Griffin (2005), pelanggan berasal dari kata custom, yang didefinisikan sebagai membuat sesuatu menjadi kebiasaan atau biasa dan mempraktikan kebiasaan. Dalam perusahaan jasa selain pelanggan dan konsumen kita juga akan mengenal istilah penumpang, dimana sebenarnya secara harfiah sendiri ridak ada perbedaan mendasar dalam mengartikan pelanggan dan penumpang, karena penumpang juga merupakan seseorang atau sekumpulan pelanggan dan konsumen yang menggunakan suatu produk yang diberikan oleh perusahaan jasa. Hanya saja istilah penumpang tersebut lebih sering digunakan bagi mereka yang menggunakan produk berupa angkutan dari perusahaan penyedia jasa terkait baik itu angkutan udara, darat, dan laut.

\section{METODE}

Pengumpulan data dilakukan dengan metode pengamatan langsung di lapangan selama 3 (tiga) bulan, wawancara kepada narasumber, dan studi pustaka melalui literatur atau penelitian terdahulu yang mendukung. Metode penelitian adalah kualitatif dengan analisis deskriptif

\section{HASIL DAN PEMBAHASAN}

Ketidakpahaman Penumpang tentang Peraturan Tatanan Kehidupan Baru dalam Perjalanan Laut.

Hingga bulan Oktober 2020, pandemi yang terjadi di Indonesia bahkan di seluruh dunia belum juga selesai. Vaksin yang ampuh menghalau virus ini juga belum ditemukan. Demi menjaga denyut nadi perekonomian, kegiatan masyarakat harus tetap bisa berlangsung. Seluruh kegiatan juga harus mengalami perubahan yang sedikit berbeda dari yang dahulu. Itulah tatanan kehidupan baru. Seluruhnya sudah diatur oleh peraturan-peraturan yang diterbitkan pemerintah Indonesia. Termasuk peraturan di lingkungan Kementerian Perhubungan, khususnya aturan bagi seluruh pengguna moda transportasi darat, laut, dan udara.

Menteri Perhubungan Republik Indonesia mengeluarkan Peraturan Menteri Perhubungan Republik Indonesia Nomor PM 18 Tahun 2020 tentang Pengendalian Transportasi dalam Rangka Pencegahan Penyebaran Covid-19. Kemudian dilakukan perubahan dengan mengeluarkan Peraturan Menteri Perhubungan Republik Indonesia Nomor PM 41 Tahun 2020 Tentang Perubahan atas Peraturan PM 18 Tahun 2020. Dari Menteri Kesehatan Republik Indonesia menerbitkan Peraturan Menteri Kesehatan Nomor 9 Tahun 2020 tentang Pedoman Pembatasan Sosial Berskala Besar dalam rangka Percepatan Penanganan Covid-19.

Dari turunan aturan tersebut diterbitkan Surat Edaran Nomor HK.02.01/ MENKES/383/2020 tentang Protokol Pengawasan Pelaku Perjalanan Dalam Negeri di Bandar Udara dan Pelabuhan dalam rangka Penerapan Kehidupan Masyarakat Produktif dan Aman terhadap Covid-19. Surat Edaran tersebut bertujuan untuk mencegah dan mengendalikan penularan Covid-19 melalui peningkatan pengawasan pelaku perjalanan dalam negeri. Kemudian menghimbau seluruh Pimpinan Kementerian/ Lembaga, Pemda, Kepala KKP, Kepala Otoritas Bandar 
Udara, dan Kepala Otoritas Pelabuhan agar menerapkan protokol pengawasan pelaku perjalanan dalam negeri di bandar udara dan pelabuhan. Di surat edaran tersebut mengatur syarat-syarat bagi pelaku perjalanan sebagai berikut:

1. Seluruh penumpang dan awak alat angkut moda trasportasi harus dalam keadaan sehat dan menerapkan protokol kesehatan.

2. Penumpang dan awak alat angkut wajib memiliki surat keterangan hasil pemeriksaan RT-PCR (Reverse Transcriptase Polymerase Chain Reaction) negatif yang berlaku paling lama 14 hari sejak surat keterangan diterbitkan dan kartu kewaspadaan kesehatan atau Health Alert Card (HAC).

Dari uraian di atas, penerapkan protokol kesehatan dan $R T-P C R$ kini sudah menjadi hal umum dan kebutuhan pada saat ini. Banyak tentunya sanksi-sanksi yang akan didapat penumpang jika melanggar aturan di atas. Khusus penumpang jika diketahui hasil $R T-P C R$ reaktif maka penumpang tersebut terpaksa tidak bisa diberangkatkan.

Selain mewajibkan memiliki surat-surat seperti di atas, para pelaku perjalanan jarak jauh akan dilakukan pemeriksaan di pelabuhan keberangkatan maupun pelabuhan kedatangan oleh petugas dari Kantor Kesehatan Pelabuhan setempat. Pemeriksaan yang dilakukan kepada pelaku perjalanan jarak jauh adalah sebagai berikut:

1. Pemeriksaan suhu tubuh terhadap penumpang dan awak alat angkut.

2. Pemeriksaan validasi surat keterangan hasil pemeriksaan $R T-P C R$ negatif milik penumpang dan awak alat angkut, dengan cara membubuhkan paraf dan stempel di sudut kanan atas.

3. Memastikan kartu kewaspadaan kesehatan atau Health Alert Card (HAC) secara manual maupun elektronik $(e H A C)$ telah diisi oleh penumpang atau awak alat angkut.
Dari surat edaran di atas sudah dapat diketahui sudah sangat jelas ada sebuah aturan yang mengatur bagaimana penanganan pelaku perjalanan jarak jauh baik untuk penumpang maupun awak alat angkut. Akan tetapi selalu ada penumpang yang tidak mengetahui peraturan tersebut. Tentu saja dengan ketidaktahuan dari penumpang tersebut bisa mengakibatkan berbagai macam masalah. Mulai teguran dari Kantor Kesehatan Pelabuhan Tanjung Emas Semarang, terhambatnya jadwal operasional kapal karena tidak seluruh penumpang melapor ke petugas, dan yang paling berbahaya adalah semakin menyebarnya virus yang menjadi pandemi hingga saat ini.

Pihak ALP Cabang Semarang sendiri berusaha melakukan sosialisasi kepada penumpang. Salah satu cara adalah dengan menyebarkan surat kepada agen tiket kapal untuk agar penumpang melaksanakan $R T-P C R$, mengisi $H A C$, dan mejalankan protokol kesehatan, semua demi keselamatan bersama.

Dari pembahasan di atas dapat disimpulkan bahwa betapa pentingnya untuk para penumpang mengetahui peraturan tentang tatanan kehidupan baru. Khusus peraturan tentang kewajiban penumpang untuk melaksanakan $R T-P C R$ mendapat perhatian dari pihak Kantor Kesehatan Pelabuhan. Bahkan jika diketahui penumpang pada $R T-P C R$ hasil reaktif, penumpang tersebut tidak bisa berangkat dan tiketnya dibatalkan.

\section{Belum Pahamnya Penumpang tentang Penggunaan $\boldsymbol{e}-\mathrm{HAC}$.}

Sesuai isi dari Surat Edaran Nomor HK.02.01/MENKES/383/2020 tentang

Protokol Pengawasan Pelaku Perjalanan Dalam Negeri di Bandar Udara dan Pelabuhan dalam rangka Penerapan Kehidupan Masyarakat Produktif dan Aman terhadap Covid-19, berisi mewajibkan seluruh pelaku perjalanan jarak jauh memiliki Kartu Pengawasan Kesehatan atau Health Alert Card. Kartu tersebut berfungsi sebagai bentuk 
pengawasan terhadap pelaku perjalanan jarak jauh yang datang dari daerah terjangkit baik internasional maupun domestik. HAC kini terdapat 2 (dua) bentuk, yaitu manual dan elektronik. Tujuan dibuatnya versi elektronik tidak lain untuk mempermudah penumpang agar bisa meregistrasikan diri mereka secara mandiri, mengurangi kontak fisik, dan mempercepat layanan petugas kepada penumpang.

Tentu e-HAC sudah jelas jauh lebih memudahkan penumpang saat pemeriksaan kesehatan. Disisi lain lebih aman karena tidak terjadi kontak fisik dengan petugas karena hanya menggunakan scan pada barcode di $e$-HAC.

Akan tetapi, hanya sebagian kecil penumpang KM. Mutiara Ferindo VII yang mengetahui adanya $e-H A C$.

Adapun alasan penumpang memilih $H A C$ manual antara lain, karena mereka gagap teknologi dan terbiasa menggunakan HAC manual. Dari hal di atas, perlu adanya sosialisasi lebih kepada penumpang tentang penggunaan e-HAC. Berikut merupakan tahap-tahap dalam memperoleh $e$-HAC sebagai berikut:

1. Penumpang harus mengunduh aplikasi e-HAC Indonesia pada Playstore di ponsel pintar masing-masing penumpang.

2. Setelah itu, lakukan registrasi dengan menuliskan email dan kata sandi.

3. Pilih menu visitor atau pengunjung pada bagiah bawah tengah menu aplikasi. Kemudian pilih lagi menu $H A C$.

4. Pilih menu HAC Card pada bagian kanan bawah layar. Terdapat 2 (dua) pilihan yang akan muncul. "HAC Indonesia" bagi penumpang yang berada di luar negeri dan akan berkunjung ke Indonesia. "HAC Domestik Indonesia" bagi penumpang perjalanan domestik. Pilih sesuai kebutuhan.

5. Isikan form yang muncul secara sebenar-benarnya. Mulai data diri, data daerah asal, dan kondisi kesehatan anda saat ini. Setelah selesai pilih menu submit.

6. e-HAC telah selesai diregisterasi, untuk melihat dapat melaui menu "Lihat $H A C^{\prime \prime}$.
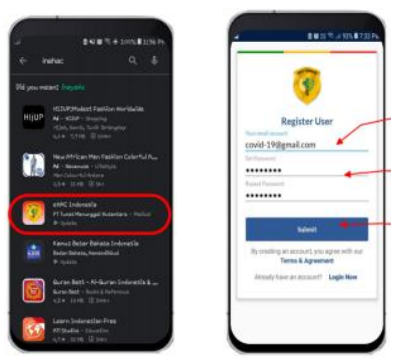

2
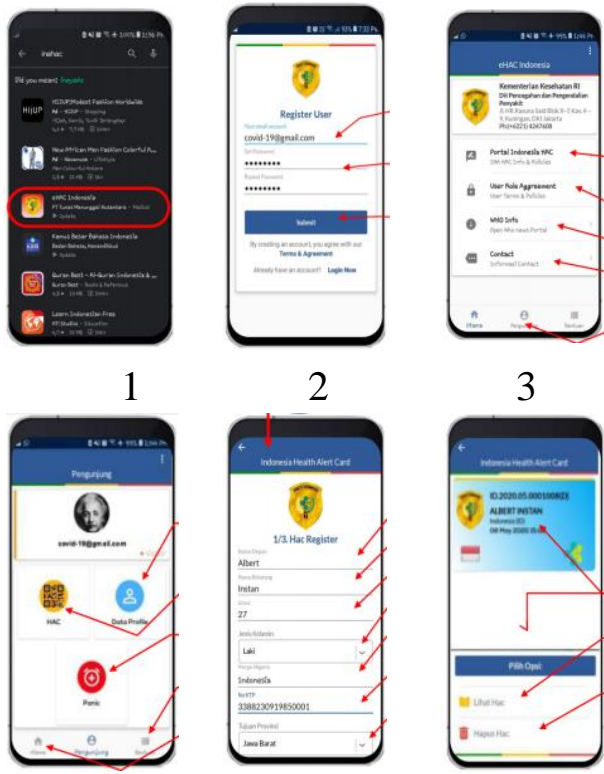

3
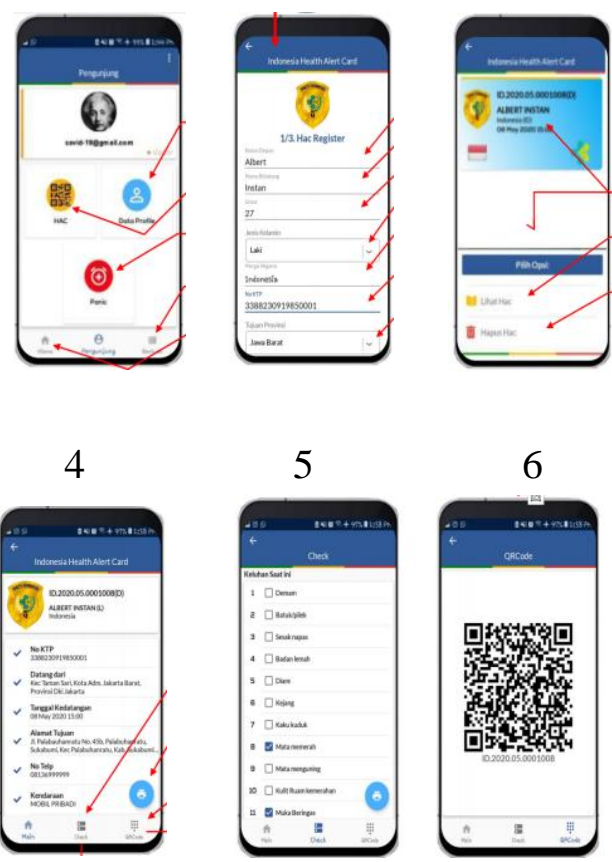

6

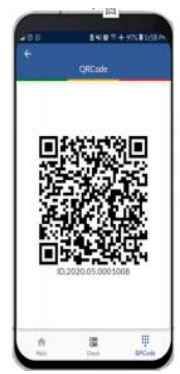

Gambar 1. Proses Pembuatan e-HAC Di Ponsel Pintar

Sumber : e-Book Panduan Pengguna Aplikasi e-HAC

Setelah melakukan pendaftaran maka penumpang bisa menampilkan e-HAC yang sudah dibuat. Berikut cara menampilkan $e-H A C$ pada aplikasi sebagai berikut:

1. Pilih menu "Lihat $H A C$ " untuk melihat $e-H A C$ yang tadi sudah dibuat.

2. Pilih menu "Cetak" untuk menyetak e-HAC. 
3. Pilih menu "QRCode" untuk menunjukan barcode untuk ditujukan kepada petugas.

Dari pembahasan ini dapat disimpulkan, $e-H A C$ merupakan pilihan baru untuk mendapatkan Kartu Kewaspadaan Kesehatan. Dalam versi elektronik ini, memiliki kelebihan lebih mudah dalam pengecekan dan mengurangi kontak fisik antara petugas dan penumpang. Diharapkan kedepannya penumpang beralih menggunakan $e-H A C$.

\section{Rendahnya Tingkat Disiplin Penumpang dalam Menjalankan Protokol Kesehatan.}

Di tengah situasi pandemi ini, segala sesuatu berjalan serba terbatas. Banyak regulasi dikeluarkan oleh pemerintah untuk mengatur bagaimana terlaksanaannya sebuah kegiatan masyarakat dengan menerapkan tatanan kehidupan baru. Tujuannya tidak lain adalah untuk menghentikan rantai penyebaran virus Covid-19 di Indonesia dan untuk menjaga tetap berjalannya roda ekonomi masyarakat.

Akan tetapi pola pikir manusia terkadang mengganggap bahwa aturan dibuat untuk dilanggar. Selama saya melaksanakan Praktek Darat, saya mendapati rendahnya tingkat disiplin penumpang dalam menjalankan protokol kesehatan. Seolah menganggap bahwa pandemi ini hanya hal sepele belaka. Jika hal ini terus saja terjadi, dibutuhkan waktu yang lama untuk bisa menurunkan jumlah korban yang reaktif terinveksi oleh virus ini. Berikut beberapa pelanggaran-pelanggaran protokol kesehatan yang dilakukan penumpang sebagai berikut:

1. Tidak menggunakan masker berakibat sanksi disiplin.

Dimulai dari hal mudah, wajib menggunakan masker bagi penumpang baik selama embarkasi, pelayaran, dan sampai di pelabuhan tujuan. Penggunaan masker bukan tanpa tujuan, menurut penelitian didapati fakta bahwa Covid-19 ini tidak menyebar melalui udara bebas akan tetapi melalui droplet. Droplet yang dimaksud adalah cairan atau cipratan air liur yang dikeluarkan seseorang dari hidung atau mulut saat bersin, batuk, bahkan berbicara. Salah satu untuk menahan droplet ini menyebar ke orang lain dengan penggunaan masker.

Kini gentar dilakukan baik dari petugas KKP, POLRI, TNI, Perhubungan, dan Pelindo III melaksanakan razia masker. Selain memberikan teguran dan sanksi kepada pelanggar, juga dilakukan pembagian masker gratis. Pihak ALP dan seluruh awak KM. Mutiara Ferindo VII juga ikut berperan aktif mengingatkan kepada penumpang untuk selalu menggunakan masker demi keselamatan bersama.

2. Penumpang tidak melaporkan diri kepada petugas KKP berakibat tidak diberikan Port Health Clearence.

Dapat kita ketahui bersama sesuai isi dari Surat Edaran Nomor HK.02.01/MENKES/383/2020 tentang Protokol Pengawasan Pelaku Perjalanan Dalam Negeri di Bandar Udara dan Pelabuhan dalam rangka Penerapan Kehidupan Masyarakat Produktif dan Aman terhadap Covid-19, berisi mewajibkan seluruh pelaku perjalanan jarak jauh memiliki Kartu Pengawasan Kesehatan atau Health Alert Card. Sudah jelas ada regulasi tertulis dari pemerintah, tetapi tetap saja ada pelanggaran dari penumpang. Pelanggaran hal seperti ini memang terlihat sepele, akan tetapi bisa menyebabkan terhambatnya jadwal operasional kapal. Contohnya tidak dikeluarkannya izin bongkar muatan dan penumpang karena tidak seluruh penumpang yang terdata di manifest penumpang melaporkan diri ke petugas KKP. Selain itu juga bisa menyebabkan tidak dikeluarkannya Port Health Clearance oleh KKP yang juga berdampak tidak keluarnya Surat Persetujuan Berlayar. Tim ALP darat dan seluruh awak selalu berusaha 
mengingatkan seluruh penumpang untuk melaporkan diri. Mulai dengan mengajak secara persuasif saat di dermaga dan keliling di kabin penumpang kapal KM. Mutiara Ferindo VII.

3. Kurang berjaga jarak berakibat sanksi disiplin.

Fakta didapati bahwa Covid-19 ini tidak menyebar melalui udara bebas akan tetapi melalui droplet. Droplet yang dimaksud adalah cairan atau cipratan air liur yang dikeluarkan seseorang dari hidung atau mulut saat bersin, batuk, bahkan berbicara. Salah satu untuk menahan droplet ini menyebar ke orang lain dengan penggunaan masker dan saling menjaga jarak. Jarak minimal agar bisa terhindar dari droplet yaitu sekitar 2 (dua) meter. Paling tidak para penumpang tidak saling berkerumun karena sangat membahayakan. Berkat koordinasi yang baik dengan PT. Pelindo III dan PT. ALP pada Terminal Penumpang Tanjung Emas sudah menerapkan jaga jarak dengan memberi tanda silang pada masing-masing kursi penumpang saat embarkasi. Selain di terminal penumpang, jaga jarak juga diberlakukan di atas kapal. Awak kapal selalu memberi himbauan untuk jaga jarak, selain itu juga memberi tanda silang di kabin-kabin penumpang pada KM. Mutiara Ferindo VII.

4. Kurang kesadaran mencuci tangan berakibat sanksi disiplin.

Fakta didapati bahwa Covid-19 ini tidak menyebar melalui udara bebas akan tetapi melalui droplet. Droplet dapat menempel pada berbagai media. Untuk mengurangi penyebaran virus ini, mencuci tangan dengan sabun sesering mungkin dengan sabun atau hand sanitaizer dengan kadar alkohol $70 \%$. Selama saya melaksanakan prada, fasilitas cuci tangan sudah ada akan tetapi masih kurang. Diharapkan baik untuk pihak PELINDO III dan PT. ALP untuk bisa menambah fasilitas cuci tangan dan menyediakan hand sanitaizer.

\section{KESIMPULAN}

Berdasarkan pembahasan dari permasalahan di atas, maka penulis dapat menyimpulkan sebagai berikut:

1. Pandemi Covid-19 membawa perubahan yang cukup luas pada berbagai bidang, termasuk sektor transportasi. Pada masa sebelum pandemi dimana tidak adanya aturan kesehatan secara khusus, kini telah berubah. Kewajiban penumpang untuk memiliki hasil RT-PCR menerapkan protokol kesehatan. Perlu ditingkatkannya sosialisasi terhadap diterbitkannya Surat Edaran Nomor HK.02.01/MENKES/383/2020 untuk meningkatkan efektifitas waktu operasional kapal dan untuk menjaga kesehatan penumpang, crew, dan seluruh pihak yang berkegiatan di pelabuhan Tanjung Emas Semarang. Tindakan persuasif baik ke pada penumpang langsung maupun melalui agen tiket kapal merupakan cara jitu.

2. Dengan berkembangnnya teknologi sekarang, maka di rilisnya e-HAC. Dengan cara pendaftaran yang sangat sederhana dan cepat, tentu bisa menjadi pilihan penumpang dalam mendapat Kartu Kewaspadaan Kesehatan (Health Alert Card). Selain mudah dan sederhana, juga mengurangi kontak fisik langsung sehingga menekan menyebaran virus Covid-19.

3. Hingga saat ini virus Covid-19 belum bisa dihentikan. Korban terinfeksi dan nyawa terus bertambah di seluruh dunia. Salah satu cara menghambat penyebaran virus ini adalah dengan melaksanakan protokol kesehatan. Melaksanakan petunjuk yaitu 3M (Mencuci tangan, Menjaga jarak, Menggunakan masker) adalah tindakan jitu untuk mencegah penyebaran virus. PT. Atosim Lampung Pelayaran Cabang Semarang terus memberikan himbauan kepada seluruh crew dan penumpang 
untuk melaksanakan protokol kesehatan demi kesehatan bersama dan menghentikan penularan virus ini di Indonesia.

\section{DAFTAR PUSTAKA}

Ali Khamdilah, Cahya Fajar, dkk., 2020, Covid-19 di Mata Dosen Sebuah Antologi Opini. Banyumas, Pena Persada.

Griffin, 2005, Customer Loyalty: Menumbuhkan \& Mempertahankan Kesetiaan Pelanggan, Erlangga, Jakarta.

Moenir, 2010, Manajemen Pelayanan Umum Di Indonesia. Bumi Aksara, Jakarta.

Poltak Sinambela, 2014, Metodologi Penelitian Kuantitatif, Graha Ilmu, Yogyakarta.

Fathiyah, 2020, Pneumonia Corona Virus Infection Disease-19 (Covid-19), Journal of The Medical Association, Vol. 70, No. 4.

Syafrida, 2020, Bersama Melawan Virus Covid-19 di Indonesia, Jurnal Sosial \& Budaya, Vol. 7, No. 6

Viryan, Charles Robert Darwin, 2020, The Origin of Species,

Undang-Undang Nomor 17 Tahun 2008 tentang Pelayaran.

Peraturan Menteri Kesehatan Nomor 9 Tahun 2020 tentang Pedoman Pembatasan Sosial Berskala Besar dalam rangka Percepatan Penanganan Covid-19.

Peraturan Menteri Perhubungan Republik Indonesia Nomor PM 18 Tahun 2020 tentang Pengendalian Transportasi dalam Rangka Pencegahan Penyebaran Covid-19.

Surat Edaran Nomor HK.02.01/ MENKES/383/2020 tentang Protokol Pengawasan Pelaku Perjalanan Dalam Negeri di Bandar Udara dan Pelabuhan dalam rangka Penerapan Kehidupan Masyarakat Produktif dan Aman terhadap Covid-19 